\title{
Cellular Localization and Regional Distribution of an Angiotensin II-forming Chymase in the Heart
}

\author{
Hidenori Urata, ${ }^{*}$ Keith D. Boehm, ${ }^{\star}$ Annie Philip, ${ }^{3}$ Akio Kinoshita, ${ }^{\star}$ Janez Gabrovsek, ${ }^{*}$ F. Merlin Bumpus, ${ }^{*}$ and Ahsan Husain * \\ Departments of * Cardiovascular Biology, and ${ }^{\S}$ Allergy and Immunology, Research Institute, \\ Cleveland Clinic Foundation, Cleveland, Ohio 44195; and ${ }^{\ddagger}$ Division of Pulmonary and Critical Care Medicine, \\ Department of Medicine, Case Western Reserve University, Cleveland, Ohio 44106
}

\begin{abstract}
The human heart is a target organ for the octapeptide hormone, angiotensin II (Ang II). Recent studies suggest that the human heart contains a dual pathway of Ang II formation in which the major Ang II-forming enzymes are angiotensin I-converting enzyme (ACE) and chymase. Human heart chymase has recently been purified and its cDNA and gene cloned. This cardiac serine proteinase is the most efficient and specific Ang II-forming enzyme described. To obtain insights into the cardiac sites of chymase-dependent Ang II formation, we examined the cellular localization and regional distribution of chymase in the human heart. Electron microscope immunocytochemistry using an anti-human chymase antibody showed the presence of chymase-like immunoreactivity in the cardiac interstitium and in cytosolic granules of mast cells, endothelial cells, and some mesenchymal interstitial cells. In the cardiac interstitium, chymase-like immunoreactivity is associated with the extracellular matrix. In situ hybridization studies further indicated that chymase mRNA is expressed in endothelial cells and in interstitial cells, including mast cells. Tissue chymase levels were determined by activity assays and by Western blot analyses. Chymase levels were approximately twofold higher in ventricles than in atria. There were no significant differences in chymase levels in ventricular tissues obtained from nonfailing donor hearts, failing ischemic hearts, or hearts from patients with ischemic cardiomyopathy. These findings suggest that a major site of chymase-dependent Ang II formation in the heart is the interstitium and that cardiac mast cells, mesenchymal interstitial cells, and endothelial cells are the cellular sites of synthesis and storage of chymase. In the human heart, because $\mathrm{ACE}$ levels are highest in the atria and chymase levels are highest in ventricles, it is likely that the relative contribution of ACE and chymase to cardiac Ang II formation varies with the cardiac chamber. Such differences may lead to differential suppression of cardiac Ang II levels during chronic ACE inhibitor therapy in patients with congestive heart failure. (J. Clin. Invest. 1993. 91:1269-1281.) Key words: angiotensin I-convert-
\end{abstract}

A portion of these studies has been presented in abstract form at the 45th Annual Fall Conference and Scientific Sessions of the Council for High Blood Pressure Research in Chicago, IL, on 24-27 September 1991 and has been published (1991. Hypertension. 18:384).

Address correspondence to Ahsan Husain, Ph.D., Department of Cardiovascular Biology, Research Institute, Cleveland Clinic Foundation, 9500 Euclid Ave., Cleveland, OH 44195-5069.

Received for publication 4 August 1992 and in revised form 18 November 1992.

J. Clin. Invest.

(C) The American Society for Clinical Investigation, Inc. $0021-9738 / 93 / 04 / 1269 / 13 \$ 2.00$

Volume 91, April 1993, 1269-1281 ing enzyme • electron microscopy immunocytochemistry • in situ hybridization • congestive heart failure $\bullet$ tissue renin-angiotensin system

\section{Introduction}

In blood, angiotensin II (Ang II ) ${ }^{1}$ is produced by the sequential processing of angiotensinogen by renin and by angiotensin Iconverting enzyme (ACE) (1). Ang II is a vasoconstrictor hormone (1), and drugs that inhibit ACE are potent antihypertensive agents (2). ACE inhibitors are also very effective in the treatment of congestive heart failure $(3,4)$. It is generally believed that the vasodilator effect of ACE inhibitors that produces a marked unloading of the failing heart is paramount to its beneficial effect ( 5 ). Recently, some investigators have proposed that direct cardiac effects of ACE inhibitors may also be therapeutically important (6).

Numerous studies have indicated that Ang II has multiple actions on the heart (7). It produces a positive inotropic and chronotropic effect by a direct action on cardiac myocytes and by stimulating the release of norepinephrine from cardiac sympathetic nerves. Consistent with these effects of Ang II, we have shown that Ang II receptors are present on atrial and ventricular myocytes and on cardiac sympathetic nerves in human heart tissue (8). Others have shown that nanomolar concentrations of Ang II produce a positive inotropic effect on isolated human cardiac trabeculae $(9,10)$. Studies on cells in culture show that Ang II is a cardiac growth factor (11). These studies clearly suggest that the human heart is a target organ for Ang II.

Paracrine regulation of human heart function by Ang II has been proposed, but the enzymatic pathways of Ang II formation in the human heart are only now being addressed $(12,13)$. Such studies are important in understanding the mechanism of action of ACE inhibitors in patients with congestive heart failure. Our recent studies indicate that the human cardiac ventricles contain a dual enzymatic pathway for Ang II formation in which ACE-dependent Ang II formation is minor $(\sim 10 \%)$ compared to a major serine proteinase-dependent Ang II formation $(\sim 80 \%)(12)$. We have isolated and sequenced this serine proteinase, a novel enzyme that is not inhibited by ACE inhibitors, and we have cloned its cDNA and gene $(13,14)$. This novel proteinase is the most efficient and specific Ang II-forming enzyme described $(13,15)$ and is the first structurally characterized human member of the chymase group of enzymes. To gain insights into factors that may regulate chymase expression and to delineate potential sites of chymase-dependent Ang II formation in the heart, we examined the regional distribution and the subcellular localization of human

1. Abbreviations used in this paper: Ang, angiotensin; ACE, angiotensin I-converting enzyme; EM, electron microscopy. 
heart chymase. Our results indicate that the cardiac interstitium may be an important site of Ang II formation in the human heart, and that several cell types, including the cardiac mast cell and endothelial cell, are the sites of biosynthesis and storage of chymase. Because Ang II has also been implicated in the pathogenesis of congestive heart failure, we have additionally examined levels of chymase-like activity and chymase mRNA in normal and failing human hearts.

\section{Methods}

Human tissue. Nonfailing donor hearts $(n=13)$ were obtained from LifeBanc (Cleveland, $\mathrm{OH}$ ). These hearts, from 10 men and 3 women ranging in age from 16 to $48 \mathrm{yr}$, were unsuitable for donation. Diseased human hearts $(n=15)$, excised from patients undergoing cardiac transplantation at the Cleveland Clinic Foundation, were the source of failing heart tissue. Each of these diseased hearts was from a patient with end-stage congestive heart failure accompanied by underlying coronary artery disease; the patients were characterized as either ischemic ( $n=5$; four male and one female, 39 to $57 \mathrm{yr}$ ), or dilated idiopathic cardiomyopathy without active myocarditis $(n=10$, seven males and three females). All heart tissue was kept in cold cardioplegia solution from the time of removal and frozen within $2 \mathrm{~h}$. Healthy human tissue including lung, liver, skin, kidney, and spleen were obtained from various patients undergoing surgical procedures at the Cleveland Clinic Foundation. The use of these tissues was approved by The Cleveland Clinic Foundation's Internal Review Committee, and consent was obtained from the donor or from his/her relatives or legal next of kin.

Electron microscopy (EM) immunocytochemistry. EM immunocytochemistry was carried out according to the method of Wolosewick et al. (16) with slight modification. Small pieces $(0.5 \mathrm{~cm}$ cubic) of tissue obtained from one nonfailing donor and one ischemic failing heart were fixed within $2 \mathrm{~h}$ from the excision in $0.1 \mathrm{M}$ cacodylate buffer, $\mathrm{pH}$ 7.3 , containing $4 \%$ paraformaldehyde at $4^{\circ} \mathrm{C}$ overnight. Tissues were further fixed in the same buffer containing $4 \%$ paraformaldehyde and $3 \%$ acrolein for $10 \mathrm{~min}$. Then the samples were postfixed in the same buffer containing $4 \%$ paraformaldehyde and $0.25 \%$ glutaraldehyde for $1 \mathrm{~h}$. The samples were washed and dehydrated by a graded series $\leq 80 \%$ ethanol. The samples were infiltrated, embedded in acrylic resin (LR White; Electron Microscopy Sciences, Fort Washington, PA), and blocked out in gelatin capsules. Blocks were polymerized for $48 \mathrm{~h}$ at $50^{\circ} \mathrm{C}$. A tissue block was sectioned on an RMC 6000 ultramicrotome, and sections were mounted on 200 mesh formvar supported nickel grid. Immunolabeling experiments and controls were repeated four times with ventricular tissue and two times with atrial tissue. Over 20 grids were examined. The surface of the sections was first etched in $1 \mathrm{ml}$ freshly prepared saturated sodium metaperiodate at $22^{\circ} \mathrm{C}$ for $15 \mathrm{~min}$. This was followed by a rinse in distilled water, an exposure for $10 \mathrm{~min}$ to $1 \mathrm{ml}$ of $0.1 \mathrm{~N} \mathrm{HCl}$, and another rinse in distilled water. Sections on the grids were then exposed to $0.5 \mathrm{M}$ ammonium chloride in $1 \mathrm{ml}$ of PBS, pH 7.4, for $30 \mathrm{~min}$. These grids were preincubated in $600 \mu \mathrm{l}$ of 20 $\mathrm{mM}$ Tris- $\mathrm{HCl}, \mathrm{pH} 8.2$, containing $0.1 \%$ BSA and $5 \%$ normal goat serum. They were incubated with the diluted $(100 \times)$ antiserum against human heart chymase (13) or with the diluted preimmune serum $(100 \times)$ in the same buffer containing $0.1 \%$ BSA and $1 \%$ normal goat serum at $22^{\circ} \mathrm{C}$ overnight. After several washes in the same buffer, these grids were incubated with $10 \mathrm{~nm}$ gold conjugated goat anti-rabbit antibody (GAR IgG Au10; Amersham Corp., Arlington Heights, IL) diluted $(30 \times)$ in the same buffer at $22^{\circ} \mathrm{C}$ for $3 \mathrm{~h}$. At the end of incubation these grids were washed several times by the same buffer and extensively washed by distilled water. Samples on the grids were contrasted with 1\% uranyl acetate (Electron Microscopy Sciences) and were examined and photographed in an electron microscope (model EM10; Carl Zeiss, Inc., Thornwood, NY) at $60 \mathrm{KV}$ with an objective aperture of 30 $\mu \mathrm{m}$ for photographs. Astigmatism caused by the magnetism of the nickel grids was checked and adjusted for each grid.
In situ hybridization. Human heart tissues were fixed in $2 \%$ paraformaldehyde in $\mathrm{Ca}^{2+} / \mathrm{Mg}^{2+}$-free $\mathrm{PBS}$, $\mathrm{pH} 7.4$, and 5- $\mu \mathrm{m}$ paraffin sections were prepared on poly-L-lysine-pretreated microslides. $10 \mathrm{sec}-$ tions from each chamber of one donor heart from a 26-yr-old male and one recipient heart from a 34-yr-old male with idiopathic cardiomyopathy were examined. An antisense oligonucleotide DNA probe corresponding to a unique 13-residue sequence of human chymase $(+17-+29$; see reference 14$)$ and its corresponding sense probe were synthesized: CTACCTGGAAATTGTAACTTCCAACGGTCCCTCAAAATTT, 126-165 bp, sense-strand;AAATTTTGAGGGACCGTTGGAAGTTACAATTTCCAGGTAG, 165-126 bp, antisense strand in the human heart chymase cDNA (14). After purification, probes were $5^{\prime}$ end labeled with $\gamma\left[{ }^{32} \mathrm{P}\right]$ ATP ( specific activity $\approx 1 \times 10^{9} \mathrm{dpm} /$ $\mu \mathrm{g}$ DNA). Hybridization was performed as previously described (17). Sections were incubated in $20 \mathrm{mM}$ Tris- $\mathrm{HCl}, \mathrm{pH} \mathrm{7.4,} \mathrm{containing} 1$ $\mu \mathrm{g} / \mathrm{ml}$ of proteinase K (type 28; Sigma Chemical Co., St. Louis, MO) and $2 \mathrm{mM} \mathrm{CaCl}$ for $30 \mathrm{~min}$ at $37^{\circ} \mathrm{C}$ after removal of paraffin with xylene. The tissue section was treated with $0.1 \mathrm{M}$ triethanolamine, $\mathrm{pH}$ 8.0 , for $2 \mathrm{~min}$ at $22^{\circ} \mathrm{C}$ and with $0.25 \%(\mathrm{vol} / \mathrm{vol}$ ) acetic anhydride in 0.1 $\mathrm{M}$ triethanolamine, $\mathrm{pH} 8.0$, for $10 \mathrm{~min}$ at $22^{\circ} \mathrm{C}$. The radiolabeled probes were incubated with the tissue sections ( $5 \mathrm{ng} /$ section) in 10 $\mathrm{mM}$ Tris- $\mathrm{HCl}$ buffer, pH 7.5, containing $300 \mathrm{mM} \mathrm{NaCl}, 1 \mathrm{mM}$ EDTA, $70 \%$ formamide ( $\mathrm{vol} / \mathrm{vol}$ ), $2 \%$ dextran sulfate, $250 \mu \mathrm{g} / \mathrm{ml}$ salmon testes DNA, and $250 \mu \mathrm{g} / \mathrm{ml}$ yeast transfer RNA for $20 \mathrm{hr}$ at $42^{\circ} \mathrm{C}$. The sections were then washed twice in $0.3 \mathrm{M} \mathrm{NaCl} / 30 \mathrm{mM}$ sodium citrate for $30 \mathrm{~min}$ at $45^{\circ} \mathrm{C}$ and once for $60 \mathrm{~min}$ at $50^{\circ} \mathrm{C}$. Slides were then coated with Ilford K. 2 nuclear track emulsion and left at $-20^{\circ} \mathrm{C}$ for 3 wk. Autoradiographic grains were developed using Kodak D-19, and the tissue was counterstained with hematoxylin and eosin Y. Adjacent sections were also stained by Malloney's alcian blue method (18). Radiolabeled oligonucleotide sense probe was also used as an indicator of background and nonspecific binding.

Southern blot analyses of human genomic DNA. Southern blot analyses of human genomic DNA were carried out by a method previously reported (14). $7 \mu \mathrm{g}$ of each leukocyte DNA prepared from three healthy volunteers was digested by the restriction enzymes EcoR1, EcoR1 + Xba1, Rsa1, Pst1, Pvu2, Hind3, or Sac1, and the resulting fragments were resolved by $0.7 \%$ agarose gel electrophoresis. Fragments that hybridized the full-length human heart chymase cDNA probe that was ${ }^{32} \mathrm{P}$-labeled by random priming were then identified by Southern blot analyses. To identify the additional fragment, if any, which is not expected based on the restriction map of the human chymase gene, the analyses were performed under low stringent wash conditions $\left(2 \times \mathrm{SSC}, 0.1 \% \mathrm{SDS}, 45^{\circ} \mathrm{C}\right)$. The patterns of restriction fragments of each blot from three different normal healthy volunteers were compared.

Northern blot analyses. Poly (A) ${ }^{+}$RNA was isolated from $1 \mathrm{~g}$ of human heart tissue using a poly (A) ${ }^{+}$RNA extraction kit (Fasttrack; Invitrogen, San Diego, CA). Poly (A) ${ }^{+}$RNA was denatured in $6.5 \%$ formaldehyde $/ 50 \%$ formamide at $65^{\circ} \mathrm{C}$, size-fractionated on a $1.2 \%$ agarose gel containing $0.66 \%$ formaldehyde, and transferred to nitrocellulose membrane, as described by Maniatis et al. (19). After crosslinking by ultraviolet irradiation, these blots were analyzed using a full-length ${ }^{32} \mathrm{P}$-cDNA probe of human heart chymase (14) under highly stringent washing conditions $\left(0.1 \times \mathrm{SSC}, 0.1 \% \mathrm{SDS}, 65^{\circ} \mathrm{C}\right)$. To compare nonfailing and the idiopathic cardiomyopathic hearts, levels of the human heart chymase mRNA expression were normalized by the level of $\alpha$-actin expression (cytoskeleton type) in the same blots.

Western blot analyses. The extraction of chymase from each tissue was performed as follows: A half gram of each tissue was homogenized in $20 \mathrm{mM}$ Tris- $\mathrm{HCl}$ buffer, $\mathrm{pH} 7.4$, and centrifuged at $40,000 \mathrm{~g}$ for 20 $\mathrm{min}$. This procedure was repeated twice. The pellet was resuspended in $20 \mathrm{mM}$ Tris- $\mathrm{HCl}$ buffer, $\mathrm{pH} 8.0$, containing $2.0 \mathrm{M} \mathrm{KCl}$ and $1 \%$ Triton $\mathrm{X}-100$, and incubated with gentle shaking at $4^{\circ} \mathrm{C}$ overnight. The mixture was centrifuged as above, and the resultant supernatant was incubated with $50 \mu \mathrm{l}$ of soybean trypsin inhibitor immobilized-agarose suspension ( Pierce Chemical Co., Rockford, IL). After extensive washing of the soybean trypsin inhibitor-agarose gel with $20 \mathrm{mM}$ Tris- $\mathrm{HCl}$ 
buffer, pH 8.0, containing $2 \mathrm{M} \mathrm{KCl}$ and the same buffer without $\mathrm{KCl}$, chymase bound to the gel was solubilized in $60 \mu$ l of SDS-PAGE sample loading buffer at $22^{\circ} \mathrm{C}$ overnight. The protein solubilized in SDSPAGE loading buffer and pure human heart chymase ( 100 and $200 \mathrm{ng}$ standard) (13) were electrophoresed on 14\% SDS-polyacrylamide gels, and the proteins were then transferred to a polyvinylidene difluoride microporous membrane using SEMI-PHOR TE 70 purchased at Hoefer Scientific Instruments (San Francisco, CA). The membranes containing the electroblotted proteins were analyzed by Western blot analyses using ${ }^{125}$ I protein A, as previously described (13).

Enzymatic assay for chymase-like activity in human tissues. A half gram of each tissue was homogenized as described above, and the pellet was resuspended in $2 \mathrm{ml}$ of $20 \mathrm{mM}$ Tris- $\mathrm{HCl}$ buffer, $\mathrm{pH} \mathrm{8.0.5 \mu l} \mathrm{sam-}$ ples, preincubated for $30 \mathrm{~min}$ at room temperature with $1 \mathrm{mM}$ EDTA, $1 \mathrm{mM} o$-phenanthroline, $20 \mu \mathrm{M}$ aprotinin, and with or without $10 \mu \mathrm{M}$ chymostatin, were incubated for $60 \mathrm{~min}$ at $37^{\circ} \mathrm{C}$ with $10 \mathrm{nmol} \mathrm{Ang} \mathrm{I} \mathrm{in}$ $50 \mu \mathrm{l}$ of $20 \mathrm{mM}$ Tris- $\mathrm{HCl}$ buffer, $\mathrm{pH} 8.0$, containing $0.5 \mathrm{M} \mathrm{KCl}$ and $0.01 \%$ Triton X-100. Generated Ang II was analyzed using a $\mathrm{C}_{18}$ reverse-phase HPLC column (Vydac, Hesperia, CA) $(13,15)$. The peak area corresponding to a synthetic Ang II standard was integrated to calculate Ang II formation. Chymostatin-inhibitable Ang II formation was considered to represent the chymase-like activity and was expressed as nanomoles of Ang II formed/minute per gram tissue (wet weight). Other known Ang II-forming enzymes including ACE, cathepsin G, kallikrein, chymotrypsin, trypsin, and carboxypeptidases were completely inhibited in this assay procedure (data are not shown).

Statistical analyses. Autoradiographic data were analyzed using a densitometric image analyzer (densitometer) driven by a MacIntosh computer. To normalize the peak area, the value of the area of interest was divided by the corresponding value of the denominator. In Northern blot analyses of nonfailing and idiopathic cardiomyopathic hearts, $\alpha$-actin was used as a denominator, and, in Western blot analyses, standardized amounts ( 100 and $200 \mathrm{ng}$ ) of the purified human heart chymase were used as a denominator. In analyzing the arbitrary unit value for the two transcripts resulting from Northern blot analyses, one-way ANOVA and Wilcoxon rank-sum tests were used for comparing nonfailing and idiopathic cardiomyopathic hearts. In analyzing chymase-like immunoreactivity and activity in the four chambers, a paired $t$ test was used for comparing the chambers. In addition to this analysis, a mixed model analysis of variance was used with heart as a random effect and the fixed effects representing the chamber type (ventricle vs atrium) and side (left vs right). In the analyses of chymase-like immunoreactivity in the middle region of the left ventricular free wall among nonfailing, ischemic, and idiopathic cardiomyopathic hearts, one-way ANOVA, and Kruskal-Wallis tests were used for making the comparisons among the groups. $P<0.05$ was considered statistically significant.

\section{Results}

EM immunocytochemical localization of chymase in the human heart. To examine the cellular localization of chymase in the human heart, EM immunocytochemical studies with a specific polyclonal antibody for human heart chymase were performed. Fig. 1 shows the localization of $10-\mathrm{nm}$ immuno-gold deposits on some but not all secretory granules of a cardiac mast cell. The degree of immuno-gold labeling in these mast cell granules was generally low. Mast cell granules that contained the immuno-gold deposits had a dense core structure surrounded by a translucent area with a lattice structure similar to that of the tryptase/chymase (TC)-type mast cell $(20,21)$. EM-immunocytochemical studies, such as those of Craig et al. (21), have also shown that human chymase is stored in mast cell granules but that the degree of labeling of the TC type mast cell granules with a human chymase antibody is relatively weak and in some cases absent. The low degree of labeling could be caused by a tight packing within granules of chymase, heparin, and other granule components (22). This type of packing may limit antigen presentation. As is apparent in Fig. 1, once released, contents of the mast cell granules show a much higher degree of labeling for chymase, which may occur because of an improvement in antigen presentation.

Immuno-gold deposits were also observed in cytosolic granules of endothelial cells located in intramural capillary. An example of this is shown in Fig. 2. The immuno-gold labeled cytosolic granules in several endothelial cells contained a microtubular structure, which is a typical ultrastructure of Weibel-Palade body containing von Willebrand factor (23). Cytosolic granules found in some mesenchymal cells of the left ventricular interstitium were also labeled with the immuno-gold deposits (Fig. 3). These mesenchymal cells were enriched in endoplasmic reticulum and contained several vacuoles. These ultrastructural properties are consistent with the properties of actively dividing fibroblasts (24).

The majority of immuno-gold deposits was observed in the cardiac interstitial region (Fig. $4 A$ ). The immuno-gold deposits appeared to be associated with the extracellular matrix. No significant immuno-gold deposits were observed in myocytes or on the sarcolemmal membrane of any of the sections examined (Fig. $4 \mathrm{~A}$ ). A low level of immuno-gold deposits, diffuse in pattern, was observed when preimmune serum was used in place of antisera against human heart chymase (Fig. 4 $B$ ); this type of labeling is characteristic of nonspecific binding.

Localization of chymase $\mathrm{mRNA}$ in the heart by in situ hybridization. To examine whether the immuno-gold deposits appearing in interstitial cell cytosolic granules are caused by chymase synthesis in interstitial cells or to protein endocytosis, in situ hybridization studies were carried out using a specific human chymase oligonucleotide probe. Dark and bright field views of a right ventricular section shows that chymase mRNA in the heart is localized in interstitial cells, as well as in endothelial cells of intramural arterioles (Fig. 5). An adjacent section stained by alcian blue for the identification of mast cells shows that several mast cells, but not the number equivalent to the number of chymase mRNA positive cells in Fig. $5 B$, appeared in the media and adventitia region of the same intramural arteriole. Fig. 6 shows bright and dark field views of a section stained by hematoxylin and eosin, showing that interstitial and endothelial cells in intramural venula also contain chymase mRNA. An adjacent section produced by the radiolabeled sense probe shows low level and diffuse distribution of grains characteristic of nonspecific binding (Fig. $6 C$ ).

Southern blot analyses of human genomic DNA. Southern blot analyses were performed using seven different restriction enzymes. One distinct hybridizing species is apparent in the EcoR1, EcoR1 + Xba1, Rsa 1, and Pst 1 digests; two in the Pvu2 and the Hind3 digests; and three in Sacl digest (Fig. 7). The human chymase gene contains one Pvu2 site; two Sacl and Hind3 sites; three Pst1 sites but no EcoR1, Xbal, and Rsal sites $(14,25)$. Since one Hind 3 and two Pst 1 fragments in the human chymase gene contain short encoding regions ( $76 \mathrm{bp}$, $50 \mathrm{bp}$, and $140 \mathrm{bp}$, respectively), these three fragments were not capable of being visualized in this Southern blot analysis. In all six different digests, however, there were no additional bands from the number expected as a result of the restriction map of the human chymase gene (14). These results suggest that, unlike rodent chymases (26-28), human chymase is likely to be a single gene product. 


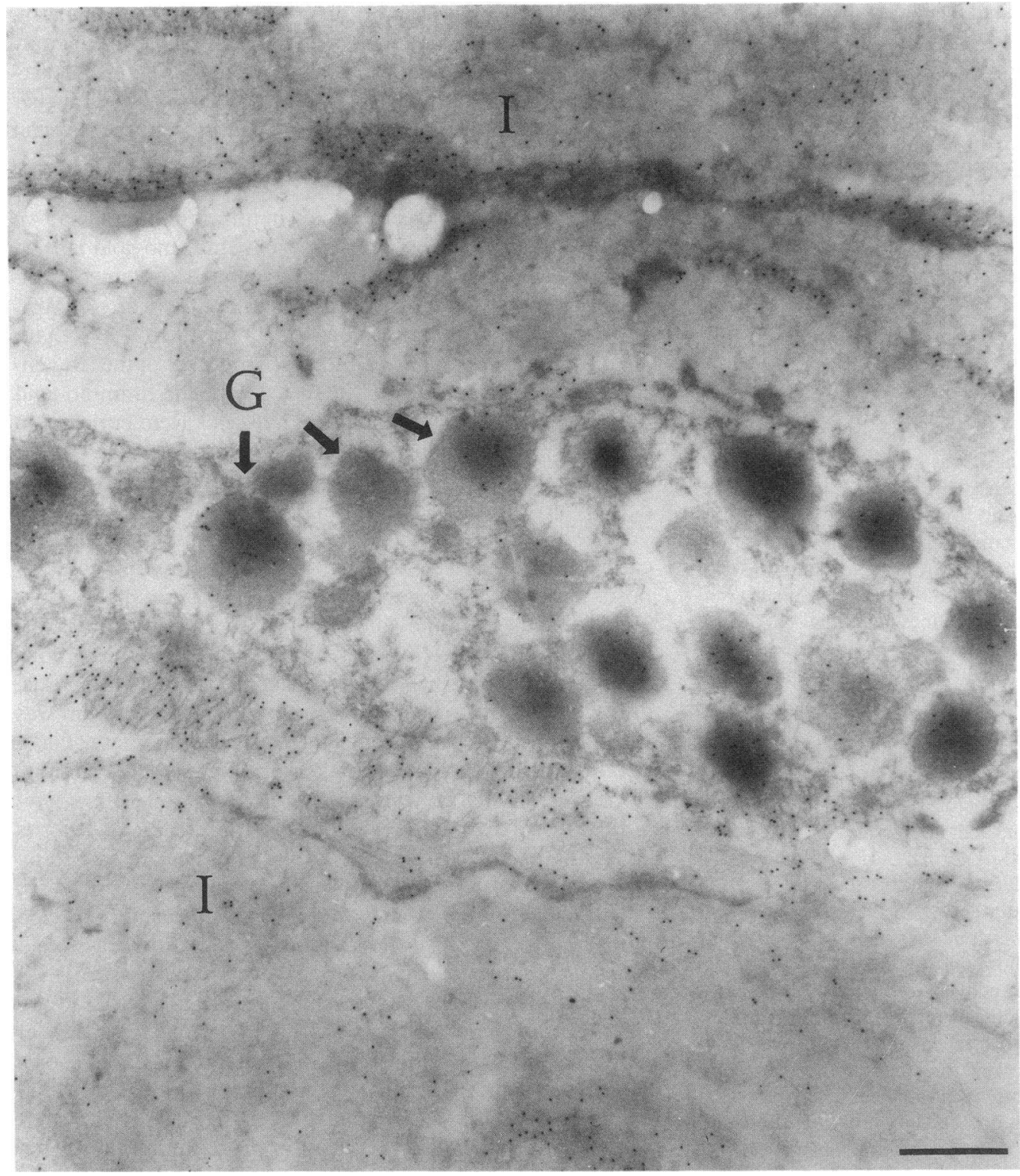

Figure 1. Immunohistochemistry of human left ventricular tissue using antichymase antibody. This tissue sample was from a donor heart of a 26-yrold male. Immuno-gold electron microscopy identifies chymase-like immunoreactivity to be localized in mast cell granules ( $G$, arrows). The cytosolic region of this mast cell is filled by large secretory granules that appear to have a dense core structure surrounded by a translucent area with a lattice structure. Immuno-gold deposits are also localized in the interstitial area $(I)$. Bar, 500 nm.
Regional distribution of chymase $m R N A$, chymase-like immunoreactivity, and activity in the human heart. An example of Northern blot analyses of chymase mRNA in atria and ventricles from a male donor is shown in Fig. 8. Two transcripts $(\sim 1.4$ and $\sim 0.9 \mathrm{~kb})$ were identified for each chamber of the heart and are likely caused by differential polyadenylation for the following reasons: $(a)$ these two bands were equally intense even under highly stringent washing conditions; $(b)$ the homology at the nucleotide level of the closest member to human heart chymase (e.g., cathepsin $\mathbf{G}$ or cytotoxic cell protease) is $\leq 50 \%(14) ;(c)$ human chymase is likely a single gene product (see previous section); $(d)$ only a single 769 -bp polymerase chain reaction product was obtained from the mRNA isolated from the nonfailing or failing hearts (14); and (e) a single chymase was purified to homogeneity from human heart tissue (13). However, an alternate promoter for the transcription or an alternate splicing of the nascent transcript is possible. No significant difference in the levels of these two chymase mRNA transcripts was found between the nonfailing $(n=8)$ and the failing idiopathic cardiomyopathic hearts $(n=10)(70 \pm 10$ vs $51 \pm 6$ arbitrary densitometric units for $1.4-\mathrm{kb}$ bands, $P=0.12$; $38 \pm 13$ vs $34 \pm 5$ arbitrary densitometric units for $0.9-\mathrm{kb}$ bands, $P=0.74$, respectively).

Northern blot analyses indicate that the ratio of the chymase mRNA to poly (A) ${ }^{+}$RNA in each cardiac chamber is not remarkably different (Fig. 8). Because there could be differences in the efficiency of mRNA extraction between regions of the heart, it is uncertain if the levels of chymase mRNA among cardiac chambers are similar or are different.

Regional differences in chymase-like immunoreactivity and activity in each chamber of five nonfailing donor hearts were estimated by Western blot analyses (Figs. 9 and $10 \mathrm{~A}$ ) and enzymatic activity assays (Fig. $10 \mathrm{~B}$ ). A significant correlation was observed between chymase-like immunoreactivity and activity in nonfailing donor heart tissue $\left(y=7.8 x+20, r^{2}=0.54\right.$, $n=18, P<0.001$ ) (Fig. $10 \mathrm{C}$ ). When analyses were done according to chamber type (ventricles, $n=10$, vs atria, $n=8$ ), both chymase-like immunoreactivity $(P<0.02)$ and activity 


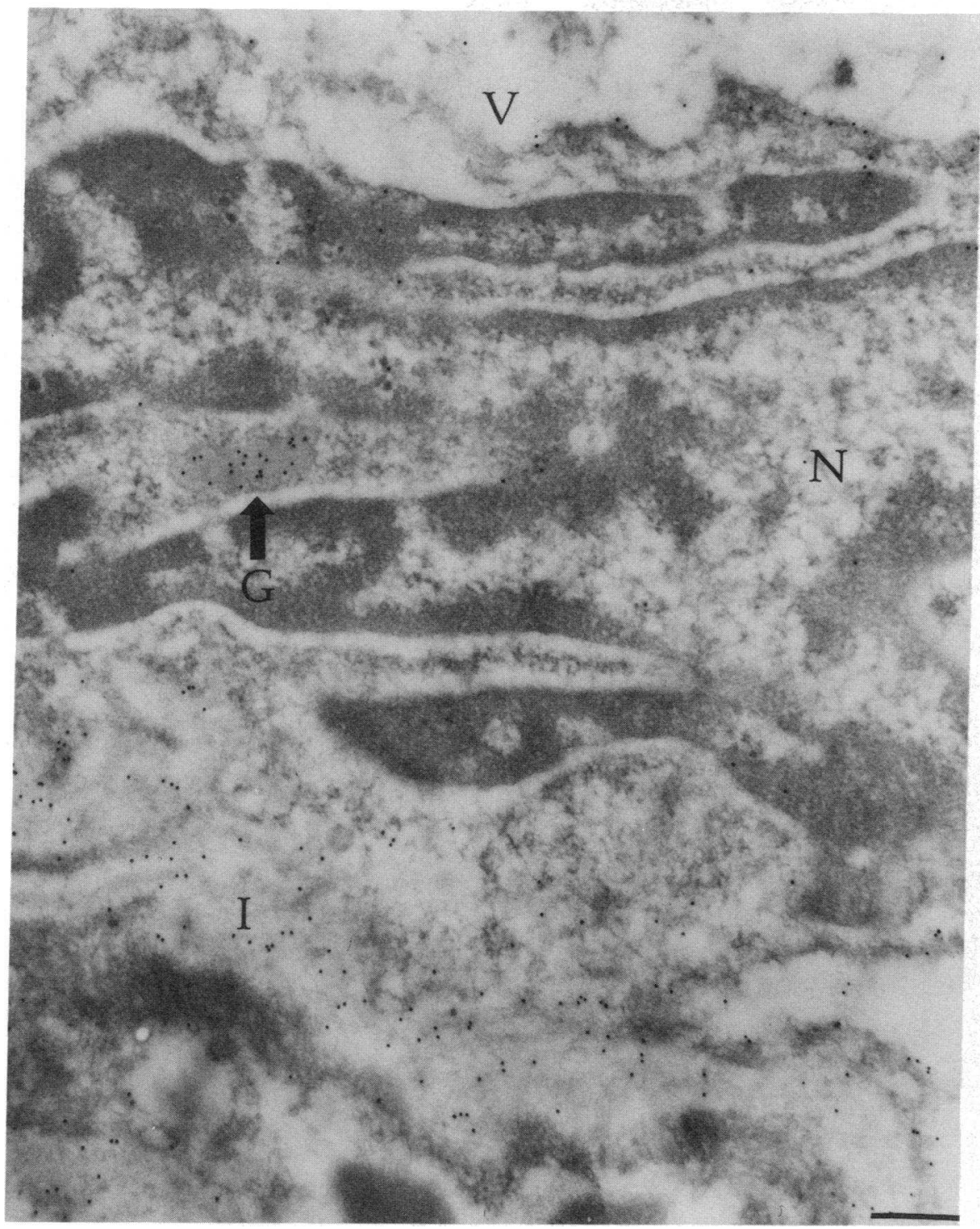

Figure 2. Immunohistochemistry of an endothelial cell from a cardiac intramural capillary using antichymase antibody. This tissue sample was from a donor heart of a 26-yr-old male. Immuno-gold electron microscopy identifies chymase-like immunoreactivity to be localized in endothelial cell granules ( $G$, arrow). This granule has an internal microtubular structure, which is a typical of Weibel-Palade body. Immuno-gold deposits are also found in the interstitial region $(I)$ surrounding this endothelial cell. $N$, nucleus of endothelial cell; $V$, capillary lumen. Bar, $350 \mathrm{~nm}$.
$(P<0.05)$ were approximately twofold higher in ventricles than in atria (chymase-like immunoreactivity, ventricles $14 \pm 1.4$ vs atria $6.9 \pm 1.1$ arbitrary densitometric units, respectively; chymase-like activity, ventricles $140 \pm 13$ vs atria $61 \pm 12$ nmol Ang II formed/min per $g$ tissue, respectively). When analyses were done according to side of the heart (right, $n=10$, vs left, $n=8)$, there was no significant difference in chymaselike immunoreactivity $(P=0.98)$ and activity $(P=0.41)$ between the right and the left heart (chymase-like immunoreactivity, right $10 \pm 1.5$ vs left $11 \pm 2.0$ arbitrary densitometric units, respectively; chymase-like activity, right $105 \pm 21$ vs left $102 \pm 14 \mathrm{nmol}$ Ang II formed/min per $\mathrm{g}$ tissue, respectively).

A summary of chymase-like immunoreactivity and activity in nonfailing human left ventricular tissue and in left ventricular tissue from patients with ischemic or idiopathic cardiomyopathy is presented in Table I. There was no significant difference in chymase-like immunoreactivity $(P=0.45)$ and activity $(P=0.45)$ among nonfailing, failing ischemic, and idiopathic cardiomyopathy hearts.

A summary of chymase-like immunoreactivity and activity in several human tissue is presented in Table II. Levels of chy- mase-like immunoreactivity and activity in the cardiac ventricles, lung, and liver were generally higher than those of observed in atria, coronary artery, aorta, kidney, and spleen. In the skin, high level of chymase-like activity was observed, but levels of chymase-like immunoreactivity were low. It is, at present, unclear whether skin tissue contains high levels of an Ang II-forming enzyme that is immunologically dissimilar to chymase.

\section{Discussion}

Our recent studies with human heart tissue suggest the presence of a dual pathway of Ang II formation in which the serine proteinase chymase is the major and ACE is the minor Ang II-forming activity (12). Chymase isolated from the human heart has a high catalytic efficiency and specificity for the conversion of Ang I to Ang II, and has been proposed to play a significant role in the paracrine regulation of heart function by Ang II $(12,13)$. In this report, we describe the cells in the human heart that are involved in the synthesis of chymase and the localization of this enzyme once it is released. These obser- 

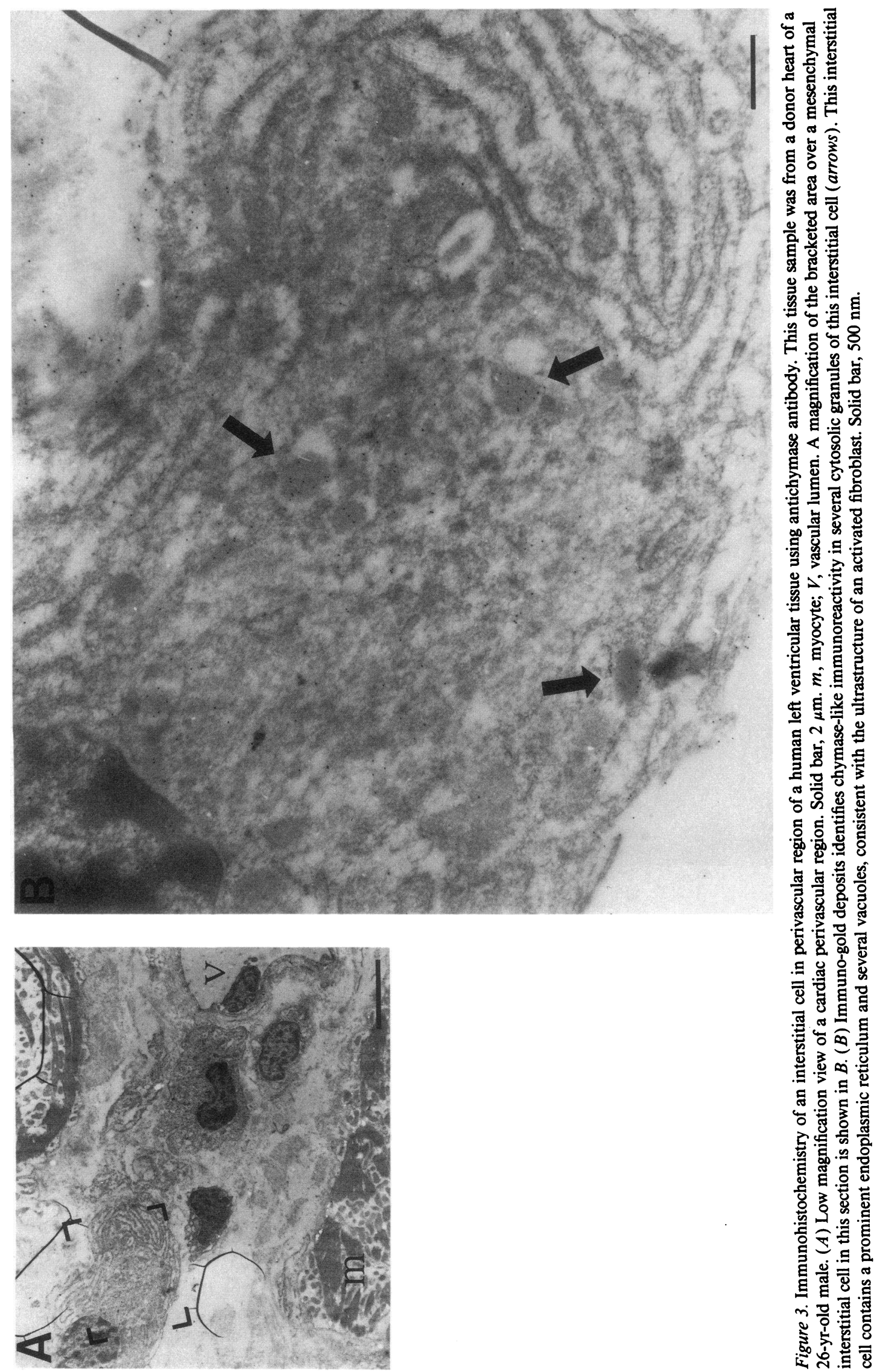

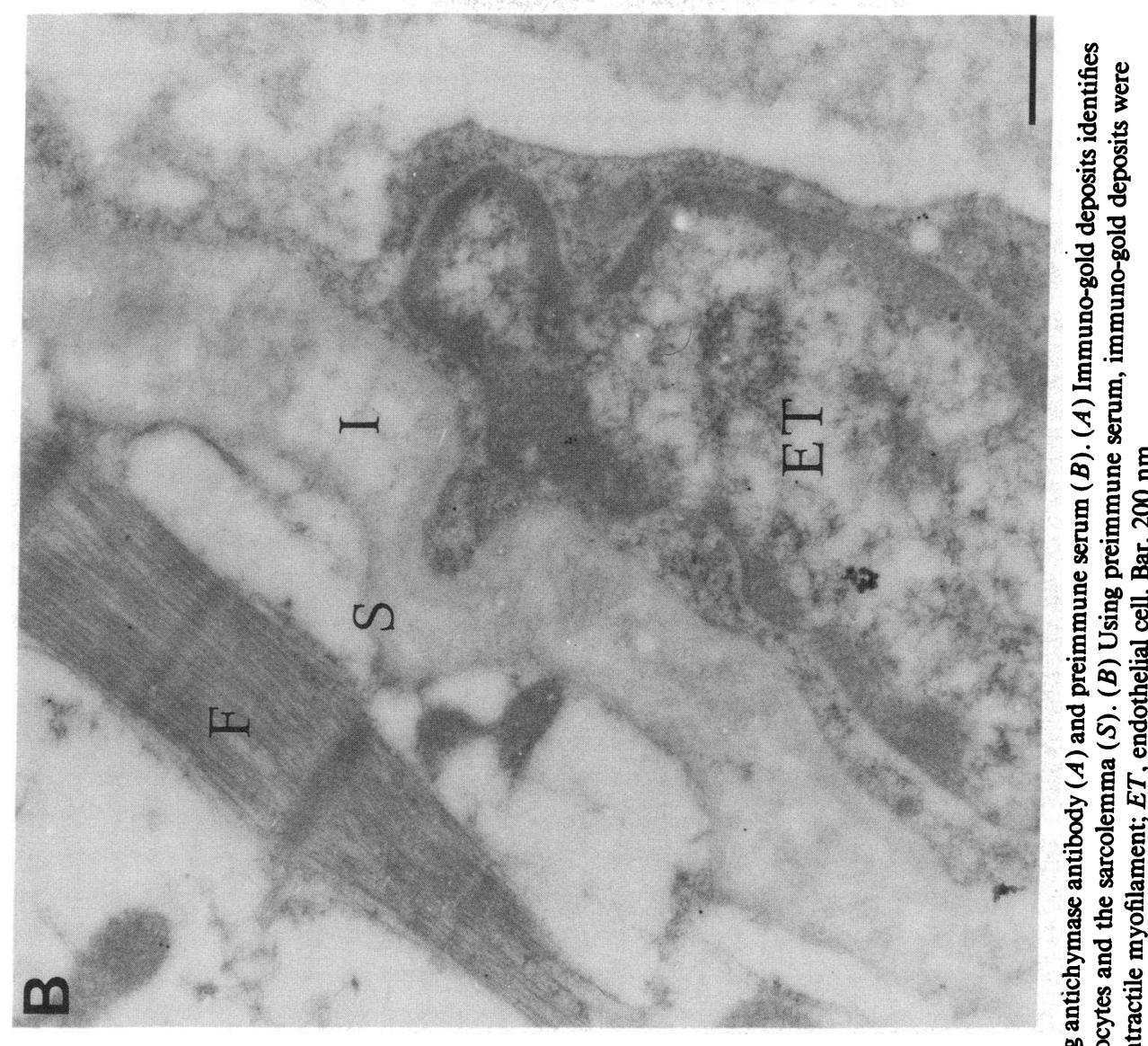

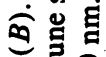

봉

总哭

㝵

国

虫西

茞它娄

ऽ。

के

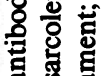

\% 융

혐

造

跑

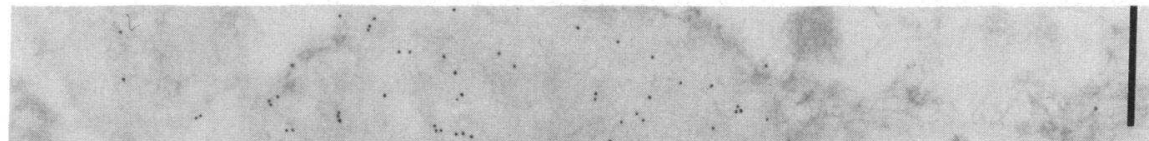

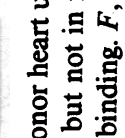

80

量逗产

范

邹

동

它

氙

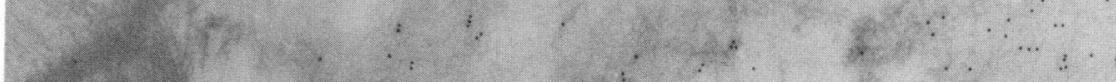

응

政

를

尊

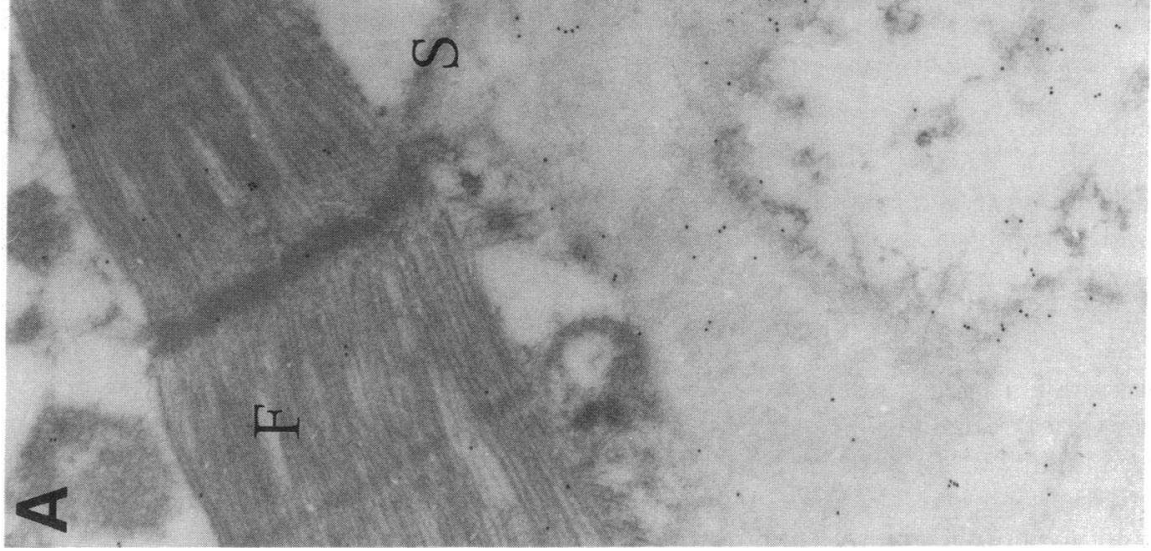

.

远递

홍

릉

8

형

是

焉

득

密总总 


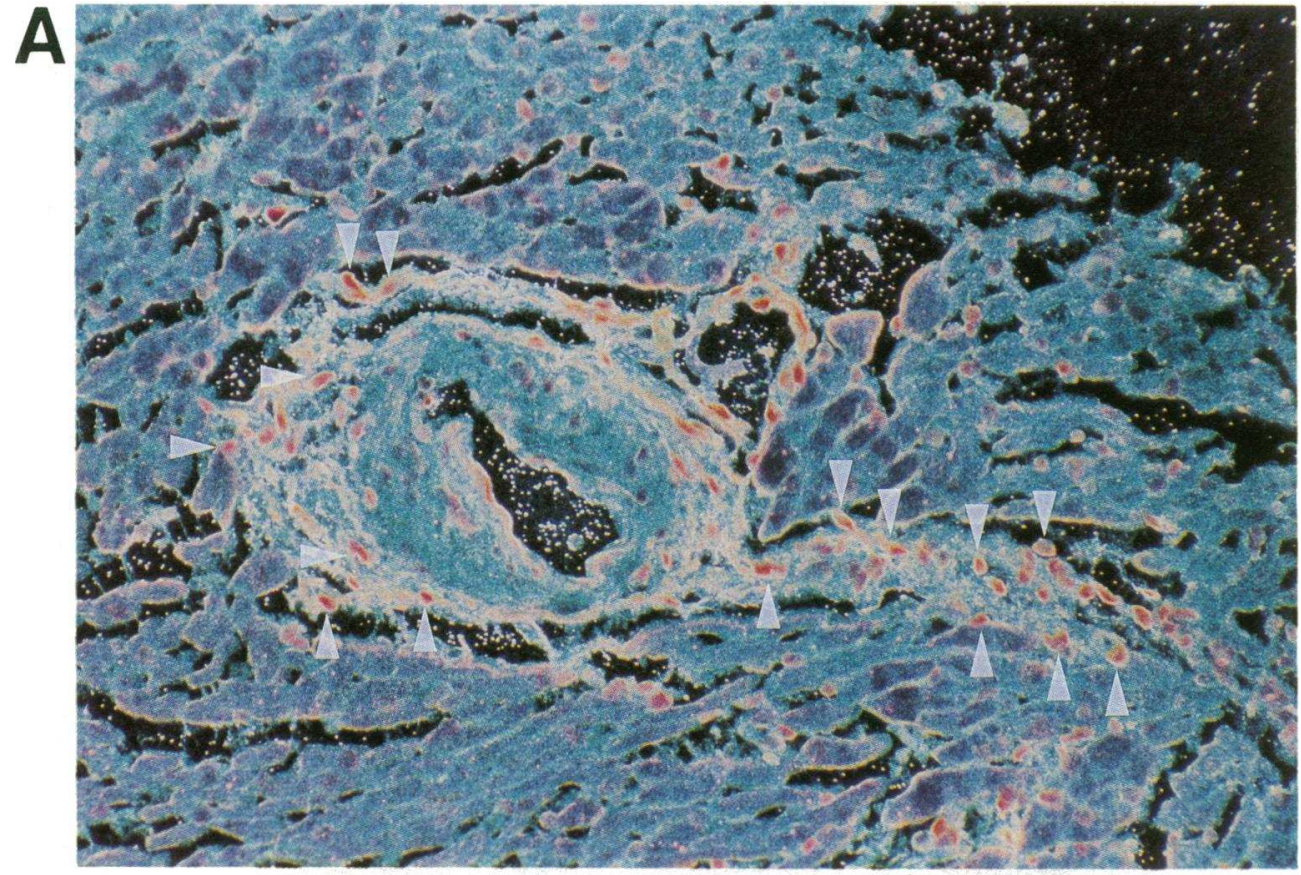

B

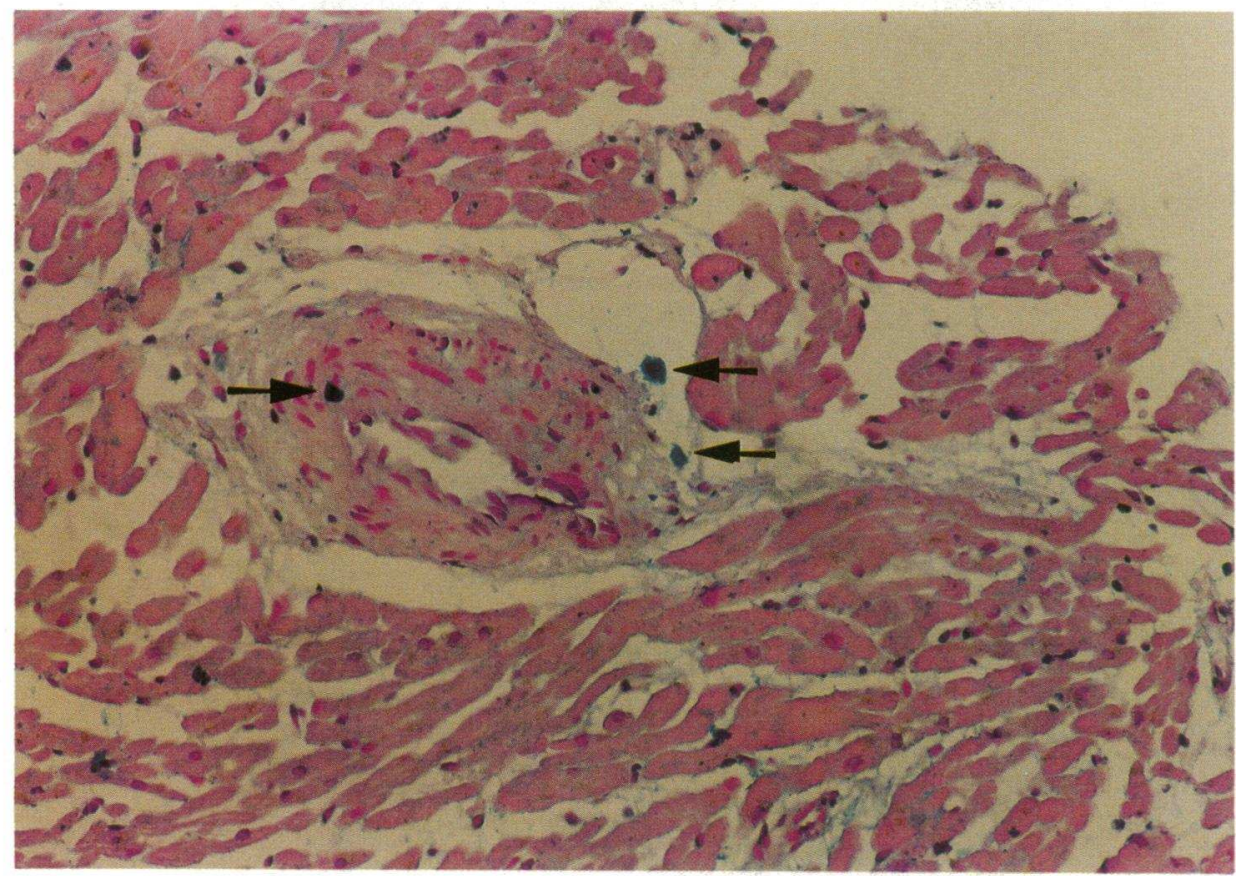

Figure 5. (A) Dark field view of a histological section of the right ventricle from a donor heart of a 26-yr-old male hybridized with a human chymase-antisense oligonucleotide probe. Bright spots represent human chymase mRNA. Several adventitial interstitial cells containing human chymase mRNA are indicated (white arrowheads). (B) An alcian blue stained histological section, adjacent to that shown in $(A)$, indicates mast cells (black arrows). $\times 200$.

vations, as well as a systematic study of the regional distribution of chymase in the human heart, provide valuable insights into the role of chymase in cardiac Ang II formation.

EM-immunocytochemical studies using a specific human heart chymase polyclonal antibody indicate the presence of chymase-like immunoreactivity in secretory granules of human cardiac mast cells. This finding was expected, since all other mammalian chymases studied have been shown to be stored in an active form in secretory granules of the mast cell $(29,30)$. A highly unexpected finding was the observation that chymase-like immunoreactivity is present in Weibel-Palade bodies of endothelial cells and in cytosolic granules of intersti- tial mesenchymal cells. These interstitial cells appeared to be actively dividing fibroblasts because of the presence of an extensive network of rough endoplasmic reticulum and cytoplasmic vacuoles (24). The human heart chymase antibody used in these subcellular localization studies did not cross-hybridize to other known serine proteinases closely related to chymase such as human neutrophil cathepsin G (13), suggesting that the vesicular chymase-like immunoreactivity was caused by chymase. To examine if unknown chymase-like proteinases highly homologous to human chymase may contribute to chymase-like immunoreactivity, Southern blot analyses of human genomic DNA were carried out using a cDNA probe compris- 

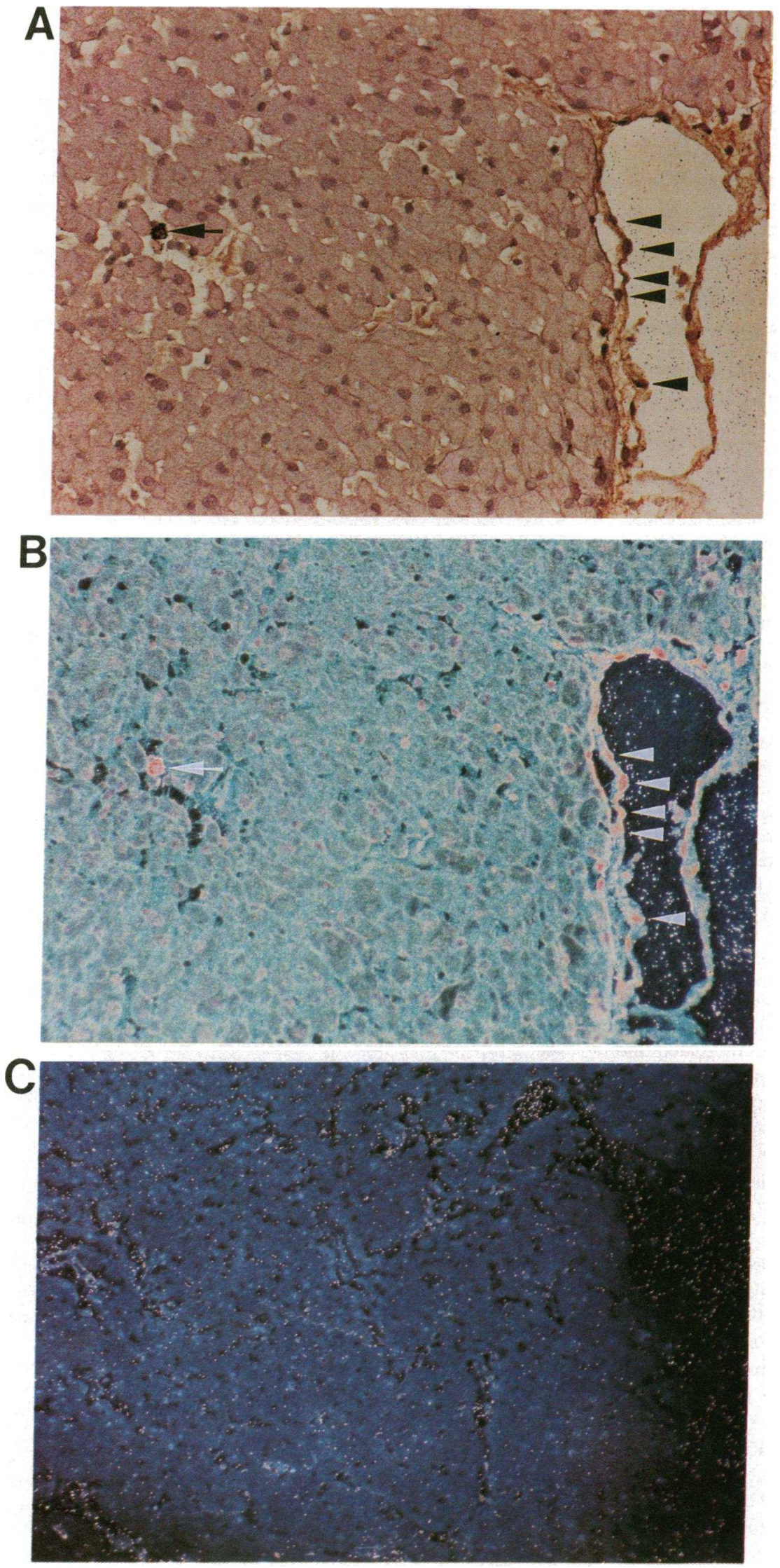

Figure 6. $(A)$ Bright field and $(B)$ dark field views of a histological section of the right ventricle from a donor heart of a 26 -yr-old male hybridized with a human chymase-antisense oligonucleotide probe. Silver grains in $A$ or bright spots in $B$ represent human chymase mRNA transcripts. Based on alcian blue staining of an adjacent section (not shown), the heavily labeled interstitial cell indicated by an arrow appears to be a mast cell. A high density of silver grains are also found in endothelial cells (arrowheads). ( $C$ ) Dark field view of a histological section, adjacent to that shown in $A$, hybridized with a sense probe complimentary to the probe used in $A$ and $B$. The staining of this tissue section by hematoxylin \& eosin was much weaker than that in $B$. Weak staining was necessary to show in a dark field view that the brightly lit silver grains in this control section had a diffuse pattern indicative of nonspecific binding. $\times 170$. 


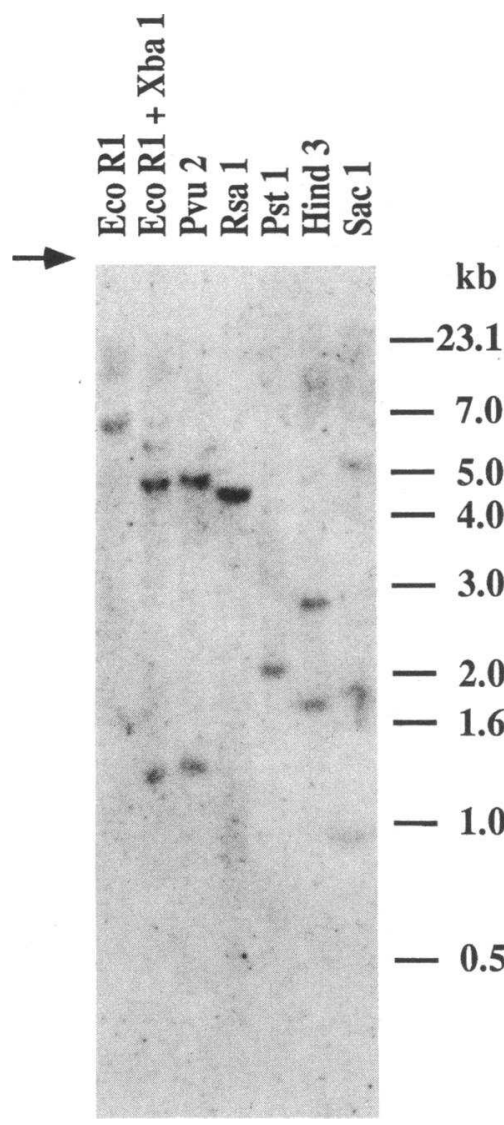

Figure 7. Southern blot analyses of human genomic DNA with human heart chymase cDNA probe. $7 \mu \mathrm{g}$ of human DNA were digested with restriction enzymes, as listed on the top of the figure. Fragments that hybridized the full-length ${ }^{32} \mathrm{P}$ labeled human heart chymase cDNA probe were identified by Southern blot analyses. The analyses was performed under low stringent washing conditions, as described. One distinct hybridizing species is apparent in the EcoR1, EcoR1 + Xba1, Rsa 1, and Pst 1 digests; two in the Pvu2 and Hind 3 digests; and three in the Sacl digest. The human heart chymase gene contains one Pvu2 site, two Sacl and Hind3 sites, three Pst1 sites, but no Eco R1, $\mathrm{Xbal}$, and Rsal sites. Since one of the Hind3 and two of Pst 1 fragments contain the short encoding region (76, 50, and $140 \mathrm{bp}$, respectively) of the human heart chymase gene, these three fragments were not capable of being visualized in this Southern blot analyses. Please note that, in any of six different digests including Rsa1, no additional bands other than those expected from the restriction map of the human heart chymase gene were found, suggesting that there is a single gene for human chymase. This Southern blot is representative of three different blots obtained using genomic DNA from three humans.

ing the entire coding region of human heart preprochymase. Extensive low stringency Southern blot analyses indicated that human chymase is a single gene product, supporting the contention that the human heart chymase antibody did not crossreact with unknown proteins highly homologous to human chymase. These observations indicate that the chymase-like immunoreactivity detected in cytosolic granules of mast cells, endothelial cells, and some interstitial cells is likely to be caused by chymase.

Based on their ultrastructural characteristics, cytosolic vesicles containing chymase-like immunoreactivity in mast cells and endothelial cells, but not those of interstitial cells, appeared to be secretory $(31,32)$. To clarify whether vesicular chymaselike immunoreactivity in interstitial cells is a product of cellular biosynthesis or occurred through protein uptake, in situ hybridization studies were carried out. Using a highly specific antisense oligonucleotide probe, chymase mRNA signal was observed in endothelial cells of the intramural venula and in several interstitial cells including mast cells. These in situ hybridization studies, as well as the EM-immunocytochemical studies, are the first to show that human chymase is elaborated

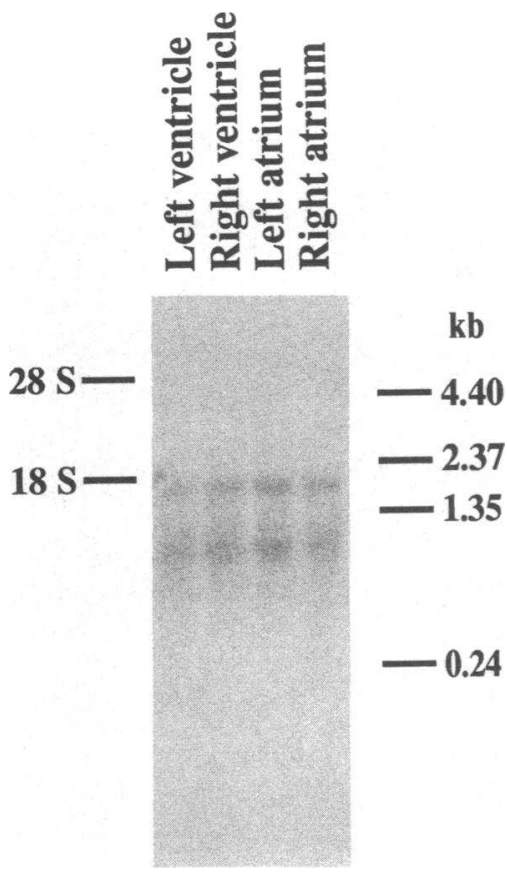

Figure 8. A representative Northern blot of chymase mRNA expression in the human heart. Poly (A) ${ }^{+}$RNA was isolated from one gram of a nonfailing donor heart and $3 \mu \mathrm{g}$ of poly $(\mathrm{A})^{+}$RNA was used for Northern blot analyses, as described. Exposure time for development was $7 \mathrm{~d}$. Two transcripts $(\sim 1.4$ and $\sim 0.9 \mathrm{~kb})$ were observed in each chamber of the heart.

in cell types other than the mast cell. This is a unique finding, since other known chymases have been described only in mast cells $(29,30,33)$. It is interesting to note that the $5^{\prime}$ and $3^{\prime}$ untranslated region of human chymase gene lacks important mast cell specific enhancer sequences found in mouse and rat chymase genes $(14,25,34)$. It is tempting to suggest that such differences in the cis-acting elements of the human chymase gene may account for its more widespread cellular distribution than other mammalian chymases. Because chymases previously have only been identified in mast cells, they have often been referred to as mast cell proteases; e.g., rat mast cell protease I, rat mast cell protease II $(29,30)$. Because chymase is present in multiple cell types in the human heart, we believe

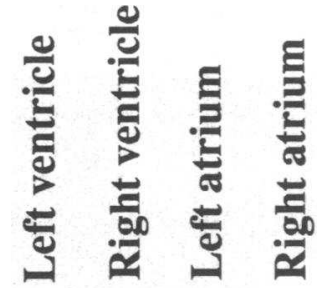

Figure 9. A representative Western blot showing chymase-like immunoreactivity in the human heart. A half gram of tissue from each chamber of a donor heart was analyzed for chymase-like immunoreactivity, as described

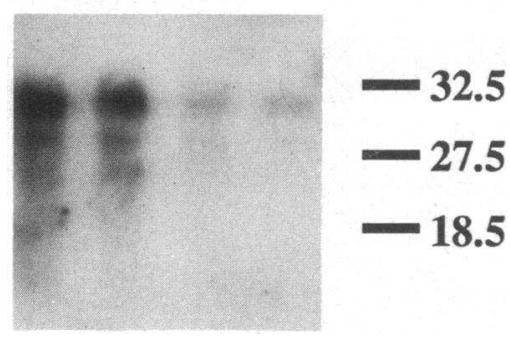
in Methods. A major immunoreactive band, $\sim 30 \mathrm{kD}$, was observed in each heart chamber, however, lower molecular weight immunoreactive bands of lesser intensity were also observed. We have

previously shown that human chymase remains active after proteolytic cuts are made in noncritical regions of the enzyme (13). However once the enzyme is cut, it appears as a lower molecular weight band when analyzed by SDS-PAGE under reducing conditions (13). 

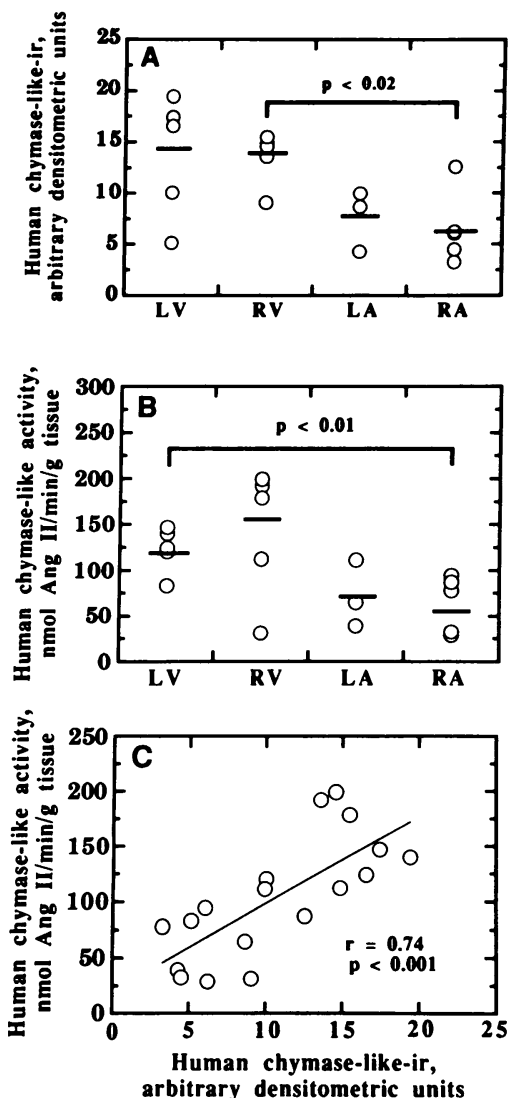

arbitrary densitometric units

that the name chymase is more appropriate than the name human mast cell protease, proposed by Jenne et al. (35). The name "chymase" is not limiting as the name "mast cell protease."

Using EM-immunocytochemistry, Kaminer et al. (36) have shown that chymase in isolated human skin mast cells is released in the extracellular space $1 \mathrm{~h}$ after a 2,4-dinitrochlorobenzene challenge; released chymase was observed attached to the extracellular matrix. High levels of chymase-like immunoreactivity are localized in the cardiac interstitium and are likely associated with the interstitial extracellular matrix. Human chymase is a highly basic enzyme (14). Molecular modeling studies on human chymase (Sung S. S., and A. Husain, unpublished observations) indicate the presence of several positively

Table I. Chymase-like Immunoreactivity and Enzymatic Activity in Left Midventricular Regions of Nonfailing and Failing Human Hearts

\begin{tabular}{lcc}
\hline \multicolumn{1}{c}{ Pathological diagnosis } & $\begin{array}{c}\text { Chymase-like } \\
\text { immunoreactivity }\end{array}$ & $\begin{array}{c}\text { Chymase-like } \\
\text { activity }\end{array}$ \\
\hline & $\begin{array}{c}\text { arbitrary } \\
\text { densitometric } \\
\text { units }\end{array}$ & $\begin{array}{c}\text { nmol Ang II } \\
\text { formed/min/g } \\
\text { tissue wet } \text { wt }\end{array}$ \\
Nonfailing $(n=5)$ & $64 \pm 14$ & $105 \pm 11$ \\
Ischemic cardiomyopathy $(n=5)$ & $36 \pm 11$ & $88 \pm 15$ \\
Idiopathic cardiomyopathy $(n=5)$ & $54 \pm 20$ & $100 \pm 12$
\end{tabular}

Table II. Chymase-like Immunoreactivity and Enzymatic Activity in Human Tissues

\begin{tabular}{lcc}
\hline \multicolumn{1}{c}{ Tissues } & $\begin{array}{c}\text { Chymase-like } \\
\text { immunoreactivity* }\end{array}$ & $\begin{array}{c}\text { Chymase-like } \\
\text { activity }\end{array}$ \\
\hline Left ventricle & +++ & +++ \\
Right ventricle & +++ & +++ \\
Lung & ++ & +++ \\
Liver & ++ & ++ \\
Left atrium & + & ++ \\
Right atrium & + & + \\
Coronary artery & + & ++ \\
Aorta & + & + \\
Skin & + & +++ \\
Kidney cortex & + & ++ \\
Kidney medulla & + & + \\
Spleen & ND & + \\
& &
\end{tabular}

$*+,<7.5 ;++, 7.5$ to 15 ; and,$+++>15$ arbitrary densitometric units. ${ }^{\ddagger}+,<30$;,++ 30 to 70 ; and,$+++>70$ nmol Ang II formed/min per $\mathrm{g}$ tissue (wet wt). ND, not detectable.

charged residues on the surface of this enzyme. In rat chymase I, these positively charged residues have been suggested to play a role in binding to heparin or to other sulfated proteoglycans and glycosaminoglycans found in secretory granules, and to the extracellular matrix (37). The highly basic nature of human chymase is common to all known proteinases found in mast cell granules including tryptase (38), carboxypeptidase A (39) and cathepsin G (40). It is also known that when these proteinases are bound to heparin or to heparan sulfate, they are relatively resistant to proteolytic degradation and to inactivation by the plasma serine proteinase inhibitor (41). Chymase in the heart may thus be relatively stable and likely remains active after binding to the extracellular matrix. This latter conclusion is supported by the fact that human chymase is active after binding to heparin immobilized on agarose (Urata, H., and A. Husain, unpublished observation). Ang II formation occurring from chymase activity associated with the extracellular matrix in the cardiac interstitium may thus be a major site of local Ang II formation in the human heart.

ACE inhibitors are widely used in the treatment of hypertension and congestive heart failure $(2,3,42)$. Because it is presumed that Ang II levels in the failing heart are reduced substantially after ACE inhibitor therapy, some investigators believe that Ang II effects on the failing human heart are deleterious (6). The level of Ang II in human heart tissue is likely regulated by two mechanisms: (a) uptake of circulating Ang II; and $(b)$ local conversion of Ang I to Ang II by ACE and potentially by chymase. In blood serum, ACE is the major enzyme that converts of Ang I to Ang II (12). By inhibiting ACE, Ang II formation in the circulation will be markedly reduced. Therefore, the fraction of Ang II in the heart that is taken up from the circulation also will be markedly reduced. Local Ang II formation in the heart caused by human cardiac ACE will also be reduced during ACE inhibitor therapy. On the other hand, since chronic ACE inhibitor therapy produces a $>300 \%$ increase in circulating Ang I levels (43), uptake of Ang I to the heart should be increased. Because chymase levels also are not reduced in cardiac ventricles of patients with idiopathic or isch- 
emic cardiomyopathy, it is tempting to speculate that chymase-dependent conversion of Ang I to Ang II in heart tissue will be increased in patients undergoing $A C E$ inhibitor therapy. We believe that the contribution of ACE and chymase to cardiac Ang II formation needs to be determined before conclusions are made about the role of cardiac Ang II in congestive heart failure. Such information may prove to be valuable in understanding the mechanism of action of ACE inhibitors and Ang II receptor antagonists in the treatment of hypertension and congestive heart failure, particularly if differences in efficacy are apparent between these drug classes.

During chronic ACE inhibitor therapy levels of circulating Ang II are only partially decreased (44). It has been suggested, but not proven, that even high doses of ACE inhibitors, produce incomplete inhibition of tissue ACE. It is conceivable, however, that during chronic ACE inhibitor therapy, Ang II formed by chymase in the heart and possibly in other tissues contributes to blood Ang II levels. To investigate the potential contribution of tissue chymase in regulating circulating Ang II levels, we determined the distribution of chymase in several human tissues. The presence of chymase-like immunoreactivity and activity in the skin, lungs, liver, and coronary arteries would suggest that tissues other than the heart may contribute to levels of circulating Ang II observed during chronic ACE inhibitor therapy. With respect to vascular chymase-like activity, it is interesting to note that Ang I-mediated contraction of monkey mesenteric and pulmonary arterial strips has been reported to be partially inhibited (by $\sim 55 \%$ ) by an ACE inhibitor, but completely inhibited by combined ACE inhibitor and chymostatin treatment (45). Chymostatin, a nonspecific inhibitor of chymotrypsin-like proteinases which inhibits human chymase, could inhibit Ang I-mediated vascular contraction by inhibiting chymase-like activity in monkey vessels.

Chymase-dependent Ang II formation may be greater in human cardiac ventricles than in atria since our study shows a twofold higher level of chymase-like immunoreactivity and activity in ventricles than in atria. ACE activity in the human heart also shows regional variations (12). Levels of ACE are approximately threefold higher in the right atrium than in the left ventricle and are twofold higher in the right ventricle than in the left. Under chronic ACE inhibitor therapy, differential changes in cardiac Ang II concentration may occur. Because of the relative distribution of ACE and chymase in the human heart, atrial Ang II levels may be reduced more significantly than left ventricular Ang II levels during chronic ACE inhibitor therapy. In addition to regional differences in levels of chymase and $\mathrm{ACE}$, differences in the enzymatic properties of chymase and ACE may also be important. Chymase and ACE are highly efficient Ang II-forming enzymes. However, unlike ACE, chymase is more specific and does not cleave bradykinin and substance $P(13,15)$. This observation would suggest that chymase-dependent Ang II formation is not coupled to the simultaneous inactivation of vasodilator peptides as has been shown with $\mathrm{ACE}$, a role perhaps more consistent with the regulation of myocyte function than with blood pressure regulation.

\section{Acknowledgments}

We gratefully acknowledge Dr. Norman B. Ratlif, Dr. Robert W. Stewart, and members of the heart transplant team of The Cleveland Clinic Foundation for supplying human heart tissue; Dr. Charles F. McTiernan, Department of Cardiovascular Biology, The Cleveland Clinic
Foundation, for kind gift of $\alpha$-actin cDNA probe and a Northern blot membrane from nonfailing and idiopathic cardiomyopathic hearts; Dr. Mark D. Schluchter, Department of Biostatistics and Epidemiology, The Cleveland Clinic Foundation, for advice and help with the statistical analyses; Dennis J. Wilk, Cynthia A. Boehm, and Jong K. Yun for excellent technical assistance; and Suzanne Hazan for editorial assistance.

This work was supported in part by grants to A. Husain from the Reinberger Foundation and the National Institute of Health (HL44201 and HL-33713). H. Urata is a recipient of a Grant from American Heart Association, Northeast Ohio Affiliate.

\section{References}

1. Peach, M. J. 1977. Renin-angiotensin system: biochemistry and mechanisms of action. Physiol. Rev. 57:313-370.

2. Waeber, B., I. Gavras, H. R. Brunner, C. A. Cook, F. Charocopos, and H. P. Gravras. 1982. Prediction of sustained antihypertensive efficacy of chronic captopril therapy: relationships to immediate blood pressure response and control plasma renin activity. Am. Heart J. 103:384-390.

3. Turini, G. A., H. R. Brunner, M. Gribic, B. Waeber, and H. Gavras. 1979 Improvement of chronic congestive heart-failure by oral captopril. Lancet. $i: 1213-1215$.

4. Cohn, J. N., D. G. Archibald, S. Ziesche, J. A. Franciosa, W. E. Harston, F. E. Tristani, W. B. Dunkman, W. Jacobs, G. S. Francis, K. H. Flohr, et al. 1986. Effect of vasodilator therapy on mortality in chronic congestive heart failure. Results of a Veterans Administration Cooperative Study (V-HeFT). N. Engl. J. Med. 314:1547-1552.

5. Fouad, F. M., S. El-Tobgi, R. C. Tarazi, E. L. Bravo, N. J. Hart, E. K. Shirey, and J. Lim. 1984. Captopril in congestive heart failure resistant to other vasodilators. Eur. Heart J. 5:47-54.

6. Hirsch, A. T., C. E. Talsness, H. Schunkert, M. Paul, and V. J. Dzau. 1991. Tissue-specific activation of cardiac angiotensin converting enzyme in experimental heart failure. Circ. Res. 69:475-482.

7. Lindpaintner, K., and D. Ganten. 1991. The cardiac renin-angiotensin system: an appraisal of present experimental and clinical evidence. Circ. Res. 68:905-921.

8. Urata, H., B. Healy, R. W. Stewart, F. M. Bumpus, and A. Husain. 1989. Angiotensin II receptors in normal and failing human hearts. J. Clin. Endocrinol. Metab. 69:54-66.

9. Moravec, C. S., M. D. Schluchter, L. Paranandi, B. Czerska, R. W. Stewart, E. Rosenkranz, and M. Bond. 1990. Inotropic effects of angiotensin II on human cardiac muscle in vitro. Circulation. 82:1973-1984.

10. Chen, S. A., M. S. Chang, B. N. Chiang, K. K. Cheng, and C. I. Lin. 1991 Electromechanical effects of angiotensin in human atrial tissues. J. Mol. Cell. Cardiol. 23:483-493.

11. Aceto, J. F., and K. M. Baker. 1990. [Sar ${ }^{1}$ ] angiotensin II receptor-mediated stimulation of protein synthesis in chick heart cells. Am. J. Physiol. 258:H806-H813.

12. Urata, H., B. Healy, R. W. Stewart, F. M. Bumpus, and A. Husain. 1990. Angiotensin II-forming pathways in normal and failing human hearts. Circ. Res. 66:883-890.

13. Urata, H., A. Kinoshita, K. S. Misono, F. M. Bumpus, and A. Husain. 1990. Identification of a highly specific chymase as the major angiotensin IIforming enzyme in the human heart. J. Biol. Chem. 265:22348-22357.

14. Urata, H., A. Kinoshita, D. M. Perez, K. S. Misono, F. M. Bumpus, R. M. Graham, and A. Husain. 1991. Cloning of the gene and cDNA for human heart chymase. J. Biol. Chem. 266:17173-17179.

15. Kinoshita, A., H. Urata, F. M. Bumpus, and A. Husain. 1991. Multiple determinants for the high substrate specificity of an angiotensin II-forming chymase from the human heart. J. Biol. Chem. 266:19192-19197.

16. Wolosewick, J. J., J. De Mey, and V. Meininger. 1983. Ultrastructural localization of tubulin and actin in polyethylene glycol-embedded rat seminiferous epithelium by immunogold staining. Biol. Cell. 49:219-226.

17. Boehm, K. D., M. F. Kelley, J. Ilan, and J. Ilan. 1989. The interleukin 2 gene is expressed in the syncytiotrophoblast of the human placenta. Proc. Natl. Acad. Sci. USA. 86:656-660.

18. McManus, J. F., and R. W. Mowry. 1960. Alcian blue staining for mast cell. In Staining Methods Histologic and Histochemical. J. F. McManus and R. W. Mowry, editors. P. B. Hoeber, New York. 137-138.

19. Maniatis, T., E. F. Fritsch, and J. Sambrook. 1982. Molecular Cloning: A Laboratory Manual. 1st ed. Cold Spring Harbor Laboratory, Cold Spring Harbor, New York

20. Craig, S. S., and L. B. Schwartz. 1989. Tryptase and chymase, markers of distinct types of human mast cells. Immunol. Res. 8:130-148.

21. Craig, S. S., Schechter, N. M., and L. B. Schwartz. 1989. Ultrastructural analysis of maturing human T and TC mast cells in situ. Lab. Invest. 60:147-157. 
22. Schechter N. M. 1990. Human chymase. In Neutral Proteases of Mast Cells. L. B. Schwartz, editor. Karger, Basel, Switzerland. 114-131.

23. Wagner, D. D., J. B. Olmsted, and V. J. Marder. 1982. Immunolocalization of von Willebrand protein in Weibel-Palade bodies of human endothelial cells. J. Cell Biol. 95:355-360.

24. Fawcett, D. W. 1986. Chapter 5. Connective tissue proper. In A Textbook of Histology. W. B. Saunders Co., Philadelphia. 136-173.

25. Caughey, G. H., E. H. Zerweck, and P. Vanderslice. 1991. Structure, chromosomal assignment, and deduced amino acid sequence of a human gene for mast cell chymase. J. Biol. Chem. 266:12956-12963.

26. Benfey, P. N., F. H. Yin, and P. Leder. 1987. Cloning of the mast cell protease, RMCP II: evidence for cell-specific expression and a multi-gene family. J. Biol. Chem. 262:5377-5384.

27. Serafin, W. E., D. S. Reynolds, S. Rogelj, W. S. Lane, G. A. Conder, S. S. Johnson, K. F. Austen, and R. L. Stevens. 1990. Identification and molecular cloning of a novel mouse mast cell serine protease. J. Biol. Chem. 265:423-429.

28. Serafin, W. E., T. P. Sullivan, G. A. Conder, A. Ebrahimi, P. Marcham S. S. Johnson, K. F. Austen, and D. S. Reynolds. 1991. Cloning of the cDNA and gene for mouse mast cell protease 4: demonstration of its late transcription in mast cell subclasses and analysis of its homology to subclass-specific neutral proteases of the mouse and rat. J. Biol. Chem. 266:1934-1941.

29. Lagunoff, D., and P. Pritzl. 1976. Characterization of rat mast cell granule protein. Arch. Biochem. Biophys. 173:554-563.

30. Woodbury, R. G., M. T. Everitt, and H. Neurath. 1981. Mast cell proteases. Methods Enzymol. 80:588-609.

31. Caulfield, J. P., S. El-Lati, G. Thomas, and M. K. Church. 1990. Dissociated human foreskin mast cells degranulate in response to anti-Ig $E$ and substance P. Lab. Invest. 63:502-510.

32. Wagner, D. D. 1990. Cell biology of von Willebrand factor. Annu. Rev. Cell. Biol. 6:217-246.

33. Sayama, S., R. V. Iozzo, G. S. Lazarus, and N. M. Schechter. 1987. Human skin chymotrypsin-like proteinase chymase, subcellular localization to mast cell granules and interaction with heparin and other glycosaminoglycans. $J$. Biol. Chem. 262:6808-6815.

34. Avraham, S., R. L. Stevens, C. F. Nicodemus, M. C. Gartner, K. F Austen, and J. H. Weis. 1989. Molecular cloning of a cDNA that encodes the peptide core of a mouse mast cell secretory granule proteoglycan and comparison with the analogous rat and human cDNA. Proc. Natl. Acad. Sci. USA. 86:37633767.

35. Jenne, D. E., and J. Tschopp. 1991. Angiotensin II-forming heart chymase is a mast-cell-specific enzyme. Biochem. J. 276:567-568.

36. Kaminer, M. S., R. M. Lavker, L. J. Walsh, D. Whitaker, B. Zweiman, and G. F. Murphy. 1991. Extracellular localization of human connective tissue mast cell granule contents. J. Invest. Dermatol. 96:857-863.

37. Remington, S. J., R. G. Woodbury, R. A. Reynolds, B. W. Matthews, and $H$. Neurath. 1988. The structure of rat mast cell protease II at $1.9-\AA$ resolution. Biochemistry. 27:8097-8105.

38. Schwartz, L. B., R. A. Lewis, and K. F. Austen. 1981. Tryptase from human pulmonary mast cells. Purification and characterization. J. Biol. Chem. 256:11939-11943.

39. Goldstein, S. M., C. E. Kaempfer, D. Proud, L. B. Schwartz, A. Irani, and B. U. Wintroub. 1987. Detection and partial characterization of a human mast cell carboxypeptidase. J. Immunol. 139:2724-2729.

40. Salvesen, G., D. Farley, J. Shuman, A. Przybyla, C. Reilly, and J. Travis. 1987. Molecular cloning of human cathepsin G: structural similarity to mast cell and cytotoxic T lymphocyte proteinases. Biochemistry. 26:2289-2293.

41. Frommherz, K. J., B. Faller, and J. G. Bieth. 1991. Heparin strongly decreases the rate of inhibition of neutrophil elastase by $\alpha_{1}$-proteinase inhibitor. J. Biol. Chem. 266:15356-15362.

42. Bravo, E. L., R. C. Tarazi, and F. M. Fouad. 1981. Hemodynamic effects of long-term captopril therapy in hypertensive man. In Angiotensin Converting Enzyme Inhibitors. Z. P. Horovitz, editor. Urban \& Schwarzenberg, Baltimore. 263-272.

43. Nussberger, J., D. B. Brunner, B. Waeber, and H. R. Brunner. 1986. Specific measurement of angiotensin metabolites and in vitro generated angiotensin II in plasma. Hypertension. 8:476-482.

44. Mento, P. F., and B. M. Wilkes. 1987. Plasma angiotensins and blood pressure during converting enzyme inhibition. Hypertension. 9[Suppl. III]:III42-III-48.

45. Okunishi, H., M. Miyazaki, and N. Toda. 1984. Evidence for a putatively new angiotensin II-generating enzyme in the vascular wall. J. Hypertens. 2:277284 . 